\title{
The Nursery Industry in the United States-Always New Frontiers
}

\author{
J. L. Green ${ }^{1}$ \\ Department of Horticulture, Oregon State University, Corvallis, OR 97331-7304. \\ A. K. Green ${ }^{2}$ \\ Consulting Historian and Research Librarian, 53rd Ave. N. Brooklyn Center, MN 55429
}

Since the founding of the American Society for Horticultural Science (ASHS) in 1903, members have addressed concerns and issues related to the U.S. nursery industry. A quick search of the society's journals for research articles on nursery crop production published since 1983 revealed 43 published in the Journal of the American Society for Horticultural Science, 103 in HortTechnology, and 184 in HortScience. A quick search of the Current Research Information System (CRIS) web site identified 966 current research projects researchers involving nursery plant production. CRIS is the U.S. Department of Agriculture's documentation and reporting system for ongoing and recently completed research projects (USDA-CRIS, 2002). A vast amount of nursery research has occurred and is ongoing in the U.S. Even though many of the nursery production questions have remained constant over time, ASHS researchers and educators have developed and disseminated timely information to address evolving issues and questions in appropriate ways as technology and societal concerns have evolved.

Today, nursery and greenhouse production is one of the largest and fastest growing segments of U.S. agriculture and was the fifth largest crop commodity group in U.S. agriculture (USDA-ERS, 2003). Nursery and greenhouse crops are among the top 5 commodities in 23 states and among the top 10 in 42 states (USDA-NASS, 2003). California, Oregon, and Florida are the top three nursery production States (USDA-NASS, 2001).

How did nursery crop production become such a significant U.S. agricultural industry? How did the industry adjust to the changes in the national, technology, and societal frontiers?

There are many accounts of the evolution of the nursery industry in the United States. In one such account titled "Growth and Development of Landscape Plants: A Science Comes of Age," Tukey (1979) reviewed the significant research contributions of ASHS members that have shaped the U.S. landscape nursery industry.

A special issue of the American Nurseryman journal was focused on "The Life and Times in the Industry" (Urbano, 1990). One section titled "People Who Make a Difference" presents accounts of nursery plant explorers and innovators. Four Centuries of Planting and Progress, $A$ History of the U.S. Nursery Industry details the triumphs and traumas of the U.S. nursery industry from its precolonial roots to 1990 (Higginbotham, 1990). In The Greening of a Continent, the establishment of key nursery regions throughout the U.S. is discussed (Higginbotham, 1990). American Ornamentals by Flemer (1990) is a detailed look at plant popularity trends. Riding the Technology Express by Smith (1990) chronicles technology advances and how they changed the industry. Retailing Renaissance is an account of retail developments since World War II (Schneider, 1990).

Davidson et al. (2000) present a brief history of the evolution of the U.S. nursery industry. Their account emphasizes the major factors affecting the location, relocation, and evolution of the U.S. nursery industry.

One of the earliest nurseries in the northeastern U.S. was established in the early 1600s by John Endicott of the Massachusetts colony; Endicott sold 500 apple trees in 1648. As the American frontier moved west and south from the early Massachusetts colony, nurseries were established on the forefront of the new frontiers. In the northeastern U.S., Bartram's nursery became prominent in Philadelphia (1728), Prince Nursery in Flushing, N.Y. (1737), and, with the opening of the Erie Canal, the Ellwanger and Barry Nursery in Rochester, N.Y. (1839). Moving westward with the advancing frontier, the Lake County, Ohio, nursery area initial development occurred in 1853.

1Professor; e-mail greenjl@science.oregonstate.edu.

${ }^{2}$ Consulting historian and research librarian.
But, let us pause and jump backward from 1853 to look at nursery development in the western regions of the U.S. The roots of the California nursery industry go back to 1769 when the Franciscans established missions in what is now the state of California. In Oregon, rapid growth of the nursery industry occurred with the opening of the Oregon Trail in 1843; Luelling moved his nursery over 2,000 miles of the Oregon Trail from Salem, Iowa, to Oregon in 1847. Henderson Luelling left the Oregon nursery in the capable hands of his brother, Seth, and moved in 1854 to a beautiful section of Alameda County that Henderson named Fruitvale. It is at Fruitvale, California, that he is credited as having planted the first commercial nursery in California. From this nursery, Henderson and his son Alfred sent forth hundreds of thousands of trees all over Calif. (Luelling, 1952). [When the Llewellyn family moved to the US from Wales, the spelling of the family name was changed from Llewellyn to Lewellyn. Around 1830, when they embraced the Quaker faith, the name was simplified to Lueling. After arriving in Oregon in 1847, it was spelled Luelling. Around 1875, after a misunderstanding between the two brothers, Seth and Henderson, Seth changed the spelling to Lewelling (McClintock, 1967. Wrenn, 1939b)].

In looking at the South, possibly the earliest plant introductions and plant nurseries accompanied the establishment of St. Augustine by the Spanish; they introduced orange, pomegranate, and fig trees to what is now Florida. Then in 1881, nurserymen from the more northern regions of the U.S. relocated as new land development and settlements occurred in Florida. Pliny Reasoner left his father's extensive nursery in Princeton, Ill., to establish Reasoner's Nursery in Oneco, Fla.

There was much traveling to and from, by land and by sea, of plants and nurserymen throughout the country during the 1800 s. It was not uncommon during the early days of the Luelling Nursery in Oregon for Henderson Luelling or one of his colleagues to make an annual trip to visit nurseries in the northeast. Henderson, on his trip east in 1851, purchased a variety of trees from Ellwanger and Barry, returning with the new stock via the Isthmus of Panama (McClintock, 1967).

An account of the timeline and development of all the prominent nurseries and the research contributions of all the prominent researchers would be lengthy. We will focus on responses of the industry in general to the ever-changing frontiers.

The nursery industry moved with the advancing American frontiers and with the advancing frontiers of technology and research. Davidson, et al. (2000) discussed the major changes in technology that changed the industry: transportation, such as the Oregon Trail, the prairie schooner, railroads, national highway system, and air transportation; introduction of machines and computers to reduce human and animal labor; development of agricultural chemicals such as pesticides and controlled release fertilizers; container production of nursery plants, and advances in irrigation.

In all historical accounts, nurseries were at the forefront of the ever changing American frontiers and accompanied horticultural developments throughout America. Spanish, English, French, and Dutch colonists brought their familiar food and landscape plants with them to the new world. They also brought their horticultural skills. Many of the propagation practices used in today's nurseries are inherited from the colonists (Geneve, 2001).

Nurseries on the new American frontiers first produced fruit and nut plants. As new orchards and other fruit plantings became established, nurseries transitioned to growing ornamental plants and remained a vital contributor to our nation's economy.

An example of one early nursery's evolution from fruit tree production to ornamental plant production is the Ellwanger and Barry Nursery, started in 1839 in Rochester, N.Y. The opening of the Erie Canal expedited the rapid development of the nursery industry in Rochester by providing transport of plants westward to newly settled regions. 
Ellwanger and Barry were among the last of the commercial nurseries in the northeastern U.S. in the 1800 s to maintain an extensive selection of fruit tree cultivars. They were able to do this, even after orders from nurseries in newly settled regions of America began to decline, because they developed new, worldwide markets. As new lands in other countries such as Australia and Korea were opened to horticulture, orders came back to Ellwanger and Barry. Even so, their attention and production turned increasingly to flowering and ornamental trees. The growing interest in private gardens and landscaped grounds in established communities favored this shifting emphasis.

Even though they supplied countless newly opened frontier markets, the nursery gradually declined from its position of leadership, due in part to the self-sufficiency of up-and-coming nurseries in the western U.S., which they themselves had previously supplied. Ellwanger and Barry entered the final phase of nursery evolution in 1856 when they subdivided a portion of their property. By 1930, nursery production in New York had fallen drastically and was trailing behind California and Oregon, the new leaders in nursery crop production (McKelvey, 1940).

The evolutionary sequence of the Ellwanger and Barry Nursery in developing into a large fruit nursery, transitioning to ornamental landscape plants as fruit plantings became established, producing for distant markets, and then subdividing, was repeated in other regions of the country as their settlements reached maturity. We will follow this evolution once again as we recall the evolution of the nursery industry and the related nurserymen's association in the northwestern U.S. at the end of the Oregon Trail.

The first apple trees were introduced into the northwestern U.S. by the Hudson's Bay Company. In 1824, Hudson's Bay Company Governor-in-Chief George Simpson, attended a banquet in London before sailing to Ft. Vancouver. One of the ladies present at the banquet table dropped some apple seeds from the dessert into the captain's waistcoat pocket and bade him in jest to plant them in the new country.

On 19 Mar. 1825, Governor George Simpson, on behalf of England and the Hudson's Bay Company, established Ft. Vancouver(The Columbian, 2003). When dining at Fort Vancouver in 1826, Governor Simpson discovered the seeds in the same waistcoat pocket and presented them to Hudson's Bay Company Gardener James Bryce, who planted them (Ellison, 1937). Today at Ft. Vancouver, on the banks of the Columbia River near Portland, Ore., still stands an aged, seedling apple tree that is over 175 years old. A nearby marker proclaims it, "the oldest apple tree in the Pacific Northwest. The seed was brought from England and planted by the Hudson's Bay Company in 1826" (Luce, 1976).

Mrs. Marcus Whitman visited Ft. Vancouver in 1836 and wrote a letter to her mother, speaking of apple, pear, peach, plum and fig trees, and strawberries along walkways and grape vines covering a summer house at the Fort (Cardwell, 1909). The grapes were catawba. Gooseberries also grew at the Fort (Cardwell, 1913). It would not be long before a wide range of vegetatively propagated, named horticultural cultivars would be brought to the northwest by Henderson Leuling via the Oregon Trail.

The date of the real start of the Oregon Trail is recognized as 1843 , the year of the Great Migration led by Marcus Whitman and John Gantt. The great migration consisted of 875 persons. The following year, more than 1,000 people traveled west in covered wagons (MECC, 1996); they were followed in 1845 by three thousand settlers (Loy, 1976). Among those traveling the Oregon Trail in 1845 was William Barlow, who started west with an assortment of grafted fruit trees. However, upon reaching Wyoming in July, he met men from Oregon who told him of the orchards at Fort Vancouver. Discouraged, Barlow dumped his entire load near Independence Rock, Wy. On arrival in Oregon, he found that there were no grafted fruit trees. He would have had a monopoly on such trees (Duruz, 1910).

In 1847,4 years after the 1843 opening of the Oregon Trail and 2 years after Barlow's trek, Henderson Lueling, a nurseryman of longstanding, brought a good variety of grafted plants to Oregon. Henderson's father, Meschach Lewellyn (note spelling), had established a family nursery in North Carolina in 1825 . After learning the nursery business from his father, Henderson developed nurseries in Indiana in $1830 . \mathrm{He}$ moved the family to Salem, Iowa, in 1836 where he set out a nursery and an orchard with some 35 varieties of apples, pears, peaches, plums, cherries, and small fruit (McClintock, 1967).
After buying a stout wagon in Spring 1847, Henderson made two boxes, each 12 inches deep and such width and length as to completely fill the wagon box. He filled the boxes with compost consisting of charcoal and earth, a combination that Henderson had found would hold water better than earth alone. In these boxes he planted about 700 grafted trees including apple, pear, quince, plum, cherry, black walnut, and shell-bark hickory, plus a few grape vines and gooseberry and currant bushes (for a detailed list of the trees, see Himes (1910) and Duruz (1941). The plants, 20 inches to 48 inches high, were protected from being browsed by the livestock by sideboards, strong strips of hickory bolted onto upright posts that set in staples on the uncovered wagon box.

With his wife and eight children in tow, Henderson started westward from Salem, Iowa, on the 17th of April, 1847 (Luelling, 1952). The nursery wagon, pulled by three yoke of oxen, was the lead wagon of the Lueling family's four wagons. Because Henderson watered the plants at least every other day, the nursery wagon maintained its maximum weight throughout the journey. A daughter of Henderson, Eliza Luelling, said "Father took more care of those trees than he did the family. Whether anyone had water or not the trees must be watered. They leafed out and bloomed on the journey and some of the bushes bore berries." During most of the trip, the family traveled alone or in small companies. The slow pace of the nursery wagon was an irritation to those traveling with them. To every discouraging criticism, Henderson responded that as long as he could take that load without endangering the safety of his family, he would stick to it. Henderson was not easily discouraged. No repairs or accidents occurred to the nursery wagon during the long trip west!

On 17 Nov. 1847, after traveling for 7 months and 2000 miles along the Oregon Trail, the Luellings arrived in the Willamette Valley with the first grafted nursery stock. All 10 family members survived the trip. And, an eleventh member, Oregon Columbia Luelling, was born on 3 Dec. 1847, less than a month after the family reached the Willamette Valley!

On 28 Feb. 1848, the Henderson Luelling family settled in what is now the city of Milwaukie, Ore. Their son Alfred estimated that about 400 or 500 grafted plants survived the long journey. The survivors included many that are still grown by nurseries today: 5 summer apple varieties including Red Astrachan; 5 autumn apples including Gravenstein; 11 winter apples including Winesap, Baldwin, Golden Russet, Northern Spy and Green Newton; 6 pear varieties including Bartlett, Seckel, and Winter Nelis; 5 cherry varieties including Napoleon (Royal Ann), Kentish, and May Duke; 3 peach varieties including an Early Crawford and Golden Cling; 3 grape varieties, and 'Siberian'crabapples (Himes, 1910. Duruz, 1941). These grafted plants, plus seeds that they also had brought with them, became the nucleus of the new Luelling orchard and nursery.

In March 1848, William Meek, a former neighbor of the Luelings in Iowa, arrived in Oregon and formed a nursery partnership with Henderson. Meek had brought 20 grafted trees in a box on the back of his wagon. These were added to the Luelling stock to establish the first nursery of grafted plant material on the Pacific Coast.

The Luelling and Meek Nursery grafted 18,000 trees in 1850. In Fall 1850, Henderson's brother, Seth, arrived from Indiana with peach, plum, and other seeds and became a partner in the Luelling and Meek firm. By Fall 1851, the grafted trees averaged about $4 \mathrm{ft}$ tall. Apple trees sold for $\$ 1$ each; plum, cherry, pear, and peach for \$1.50 each. Luelling and Meek advertised 60 varieties in all. By 1853, there were four branch nurseries of the Luelling and Meek Nursery in various locations in the Willamette Valley stocked with 100,000 grafted plants. Branch nurseries were located in Salem, Ore., a second in Polk County near Dallas, Ore., a third on the Long Tom River near Monroe, Ore., and a fourth near Albany, Ore. (Luelling, 1952). Also, in 1853, Seth's records included sales of roses, lilac, dahlia, Althea spp., and flowering almond. In 1855, Seth ordered magnolia, paeonia, and mulberry from William Prince of Long Island on the East Coast. By 1860, Seth's sales list expanded to include catalpa, ailanthus, English walnut, and snowball (Lewelling, 1850-1860). The nursery was in transition from offering solely fruit plants to offering landscape plants. The evolution of the nursery has been complete, and today it is the city of Milwaukie, Ore.

Seth Lewelling introduced many new fruit varieties. The 'Black Re- 
publican' cherry was introduced in 1860. A great admirer of Abraham Lincoln, Seth belonged to the Black Republican party, and, saying he would make the people relish Black Republicans, he gave his newly propagated cherry that name. The 'Bing' cherry, introduced in 1870 , was named in honor of Seth's Chinese foreman, Ah Bing. Bing, from China, was renowned to be $6 \mathrm{ft}$ tall. As Seth stated, "I'll name this for Bing. It's a big cherry, and Bing is big" (Wrenn, 1939b). Seth also developed the 'Lincoln' cherry, 'Sweet Alice' apple, and the 'Luelling' grape (McClintock, 1967).

Numerous other early nurseries and plant varieties flourished in the northwestern U.S. in the 1800s. For instance, George Settlemeir began a nursery near Oregon City and soon had the largest selection of fruit and ornamental trees in the Oregon Territory.

In 1847, The R.C. Geer and Co., located about 4 miles south of the present day Oregon Garden near Silverton, was established with a bushel and a half of apple seeds and a half bushel of pear seeds. In the early 1850 s they bolstered their nursery stock by obtaining grafted fruit trees from Henderson Luelling. In1858, Geer had 75,000 apple and 6,000 pear trees for sale. Over the next several years, the Geer nursery expanded to include grapes, cherries, peaches, plums, nectarines, and almonds (Cardwell, 1909).

J.W. Ladd arrived in Oregon in 1852 with 2,300 fruit and nut trees by way of the Isthmus of Panama. The earliest record of ornamental shrubs being shipped into Oregon are those brought by Percy W. Gillette from Ohio in 1852. Twenty-five varieties of roses were in that shipment (Pacific Monthly, 1902).

Northwestern U.S. nurseries were an important component in the early development of orchards in the northwestern U.S. An orchard planting boom occurred from 1902 to 1909 near Hood River and from 1900 through 1912 in the Willamette Valley. By 1919, there were 100,000 acres of apples in production in the Willamette Valley (Zielinski, 1976). After the arrival of Lueling's traveling nursery in 1847, plant nurseries became a major industry in Oregon (McClintock, 1967).

The growth of the nursery industry across the U.S. was accompanied by growth of state, regional, and national nurserymen's associations. An example is the Oregon Association of Nurserymen (OAN), 1893 to 1906, 1933 to present. Concerns expressed in reports at the 1895 OAN meeting were many, and many remain as current issues today (Brownell, 1895). Several of their major concerns are discussed below.

\section{INTRODUCTION AND EVALUATION OF NEW VARIETIES}

The Dominion Experimental Farm in British Columbian had 92 varieties of apples bearing and exhibited in 1895 . "We can thus, without expense to ourselves, learn what varieties of apples to grow and what not to grow... We are living in an age of novelty. The nurseryman going out must have something to attract attention." However, Brownell commented, "I think there have been many varieties sent out that should never have been sent out . . the planter did the testing. It may make a profit for a time, but it will surely do an injury in the long run" (Brownell, 1895).

There continues to be great diversity in the plants produced in Oregon. The 1997 OAN Buyers' Guide (Oregon Association of Nurserymen, 1997) listed 623 genera, 1299 species, and 1331 cultivars of plants produced by Oregon nurseries.

\section{PRODUCTION AND PRICING}

"But a few years ago, it was an easy matter to sell large numbers of fruit trees at a fair price... Then the acreage of every nursery was increased, and many others...planted small nurseries hoping to grow rich... The hard times came and the nurseries all over our country were caught with an over supply. With a great many of our nurserymen, their only idea of disposing of trees, is to lower the prices of some one else... so it has been cut, cut, cut until there is scarcely anything left to cut" (Brownell, 1895).

The acreage of early nurseries doubled in a 10-year period from 1,072 acres in 1899 to 2,298 acres in 1909 when production was valued at $\$ 1,050,853$. By comparison, the 2001 annual farm gate value of nursery and greenhouse crops in Oregon exceeded $\$ 842$ million from the 45,200 acres of Oregon's 2,139 operations.

\section{REGIONAL ADVANTAGES}

G.W. Henry stated, "We think some of our Eastern brethren would be somewhat surprised were they to see the strong, vigorous growth young trees make in nurseries on this coast.... Ten feet from bud the first year is not uncommon growth for young plum trees. ... Fruit and ornamental trees and plants in great variety adapt themselves to our soil and climate" (Brownell, 1895).

The Pacific Coast Nurserymen (PCN), encompassing nurserymen from Washington, Oregon, Idaho, California, Montana, Utah, and British Columbia, was formed in 1903 and continued until 1939. Several of the early problems discussed at the PCN meetings were proper labeling, proper handling of stock to keep it dormant late enough in the spring, need for better relations between customers and nurserymen, need to eliminate scalawags from the business, the problem of freight rates, and, the need to secure legislation more favorable to the nurserymen (White, 1975). The importance of testing of new varieties of fruits, shrubs and trees by the Agricultural Experiment Station was emphasized by Thornber (1906) at the 1906 annual meeting of the PCN.

Labor availability and cost were major concerns recorded in the early Proceedings of the Pacific Coast Nurserymen (PCN). In the 1907 Proceedings, PCN President, F.W. Powers (1907) stated, "Probably one of the most trying features in the nursery business today is securing suitable help, as work in railroad building and other lines has taken nearly all the supply of laborers at higher prices than we can afford to pay at the present price of trees." The challenge of securing labor continues today as growers say, "We just can't hire people."

\section{PLANT QUARANTINES -SHIPMENT}

Since settlement of the territory and establishment of the orchards in the early 1900s, the Pacific Northwest has been an exporter of nursery plants to other states. As early as 1908 , a PCN committee was formed to address export issues. "The interest of the Pacific Coast Nurserymen's Association in horticultural laws of the states was as great as anywhere in the country since they were basically exporters of stock to other states" (White, 1975). To ensure healthy plants and protect against plant quarantines, in 1911, the PCN appointed a Crown Gall Committee and financed planting an experimental orchard of 4,000 trees by the Oregon Agricultural Experiment Station at Oregon Agricultural College in Corvallis (White, 1975). The Committee, funding, and the Crown Gall Research Project continued at Oregon State University until 1997. Since the arrival of Leuling's traveling nursery wagon in 1847 , Oregon has been exporting nursery plants back out of the state. In 2001, $72.7 \%$ of all nursery and greenhouse plants produced in Oregon were shipped out of the state. The largest percent (14.0\%) was shipped to the northeastern states, with shipments to the upper midwestern (13.6\%) and to the Atlantic states (12.7\%) being close behind.

\section{PLANT INTRODUCTIONS HAVE TRAVELED A TWO-WAY STREET}

The history of the U.S. nursery industry would not be complete without additional discussion of plant introductions to U.S. nurseries and from U.S. nurseries to other countries. The ongoing nursery activity of plant introductions often has been followed by selection and breeding to obtain plants better adapted to local climates and needs. An example is the import and subsequent breeding and selection of yews for cold hardiness (Cochran, 2000). In 1862, George R. Hall of Warren, Rhode Island, a missionary to Japan, imported Taxus cuspidata and its Japanese variety Taxus cuspidata var. nana into America from Japan. Hall introduced the plants to the nursery trade in the northeastern U.S. through the Parsons Nursery at Flushing, Long Island, N.Y. However, they were susceptible to winter damage. Around 1904, Theophilus D. Hatfield, gardener at the Hunnewell Estate, Wellesley, Mass., experimented with seedling yews. In a propagation paper presented in 1929 titled "Yews," Hatfield indicated that the seedlings were probably a cross of the English (European) Taxus baccata and the Japanese T. cuspidata. Several seedlings, according to Hatfield, proved perfectly hardy. These cultivars, reproduced from cutting propagation, have become widely grown in the nursery industry (Shugert, 1985). 
A second example of plant introduction is the kiwi fruit (Actinidia deliciosa) (Cal Harvest Marketing, Inc, 1996). The kiwi fruit is indigenous to Southeast Asia where it has been known to the inhabitants of China and Southeast Asia since ancient times. The kiwi fruit's path to the U.S. supermarket produce section is a global story spanning nearly 700 years. The USDA first introduced kiwifruit to the U.S. in the 1930s. Plants were distributed for trial in the southern and western U.S., but the fruit was not quickly accepted by consumers. Most plants disappeared from the gardens in which they were planted, but one of the plants originally introduced in 1934 thrived at the USDA Plant Introduction Station in Chico, Calif. It became the showpiece vine for the future California kiwifruit industry. A cutting planted in Chico in 1935 has served as a source of propagating material for today's California vineyards and is still producing well. A pioneer in the kiwifruit nursery business, $\mathrm{Cal}$ Chico, Inc., began promoting kiwi fruit plants in 1971. They grew and sold thousands of plants. Kiwi fruit, a relatively unknown crop several decades ago, has gained worldwide acceptance. Now it is a major fruit crop with 170,000 acres planted in both hemispheres.

There are numerous other accounts of the U.S. nursery industry's role in introducing new and improved food and ornamental plants into the U.S. But the U.S. nursery industry has also been instrumental in introducing plants to other countries. Plant introduction and transfer has been a well-traveled, two-way street.

John Bartram was a nurseryman in the colonies and founded one of America's foremost plant nurseries in Philadelphia in 1728. He is credited with having introduced 200 species of North American plants to Europe (Independence Hall Association, 2000).

In 1803, U.S. President Thomas Jefferson sent Meriwether Lewis and William Clark west to discover an efficient route to the Pacific Ocean and to study new plant and animal life. Of the 202 plant specimens they brought back to Washington, D.C., nearly 80 were new to science, including the flowers that would become symbols for the future states of Oregon, Idaho, and Montana (The Academy of Natural Sciences, 2002).

Botanist David Douglas, on a collecting expedition in 1823 for the Royal Horticultural Society of England, made his first of several visits to what is now the state of Oregon. From Oregon, he introduced to England some 50 trees and about 100 herbaceous plants, including the douglas fir (Pseudotsuga menziesii) (Mendelson, 2002).

In 1858, a nursery seed shipment arrived at the Ellwanger and Barry Nursery in Rochester. The seed was not from Europe, but arrived by pony express from G.H. Woodruff, a gold hunter in California (McKelvey, 1940). The seeds, from the sequoia giants, were carefully planted under glass and later transplanted into pots. About 4,000 of the seeds developed into healthy plantings. Hundreds of the trees were shipped to Europe; other hundreds were scattered about the eastern U.S.

\section{CONCERNS FOR THE FUTURE}

Many of the challenges mentioned in the minutes of the early industry meetings and effects of plant introductions continue to be today's challenges and concerns for the future.

INVASIVE PLANTS. A current awareness issue regarding plant introduction and thus nursery production is the issue of invasive plants. Invasive plants are a side effect of plant exploration, introduction and nursery production (Hall, 2000). According to Hall, "The search for successful, beautiful plants has often led to the introduction of very successful invaders. At least half of all of the plant invasions in the United States have been by garden plants" (Turning Point Project, 1999).

Sarah Reichard and Faith Campbell (1996) stated that $85 \%$ of the 235 woody invasive plants in the United States were originally introduced as ornamental or landscape plants; an additional 14\% were introduced as agriculture plants. "The nursery industry has been and still is an important vector for the spread of invasive plants throughout the United States" (Campbell, 1999). Of the 454 plants listed on Campbell's list of plants that hog the garden, 292 (60\%) were still being sold in nurseries. The invasive plant issue is a current and future concern of the nursery industry.

RELOCATION OF THE NURSERY INDUSTRY. Where will our nurseries be located? Because of state, national, and international plant quarantine regulations, nursery plant production has been relatively localized. Many industries and production of several agricultural crops have located and relocated globally based on economic factors such as favorable climate, labor, and transportation. The nursery industry is gradually becoming more of an international, rather than localized, industry.

In the nursery industry today, unrooted cuttings and in vitro tissuecultured plants, as well as many species of larger plants produced in soilless systems or in sterile substrate with no contact with soil, are international commodities. The micropropagation industry has seen tremendous expansion globally from 1985 to 1990 in the number of businesses as well as in the number of plants produced annually (Govil and Gupta, 1994). Much of the increased production is attributed to expansion of production in India. The Indian micropropagation industry expanded exponentially from 1987 to 1993, and facilities in use in India are comparable to those in countries such as The Netherlands and the U.S. Globally, 5200 million tissue-cultured plants were produced in 1990 for an estimated global market of $\$ 15,000$ million per annum. However, in The Netherlands and the U.S., this industry is finding it difficult to be cost-effective due to cheaper production in countries with lower wage scales.

With the increased restriction of international migration of relatively inexpensive manual labor, it has been economically advantageous to relocate labor intensive industries to countries that have relatively inexpensive labor. The alternative of substituting mechanization and automation for manual labor has occurred to a limited extent. While reducing the requirement for manual labor, automation-mechanization may increase the energy requirements and substitute technical labor positions for manual labor positions.

With increasing concerns regarding per capita energy consumption and the cost of energy, it is becoming economically advantageous to relocate climate-dependent industries, such as nursery crop production, to regions with favorable ambient climatic conditions that require little or no energy for climate modification and control. Distance of production from market must also consider the energy costs of transportation. Also, radically new engineering concepts and designs for protected plant culture (Achten,1999) may reduce energy input sufficiently to slow the relocation to favorable climates.

Potential changes in global climates may also result in relocation of current nursery production areas (Schulze and Kunz, 1995). According to the climatic threshold model used in southern Africa, the timber species and horticultural crops will shift westward to new climatically suitable areas in the future. The results also indicate that climate change resulting from the greenhouse effect may benefit the horticultural industry to a greater extent than the timber industry (Schulze and Kunz, 1995). However, we must keep in mind that water is the single most limiting factor affecting crop production worldwide (Peterson, et al. 1997).

The nursery industry and the research community are addressing international societal concerns related to resource conservation and protection of the environment. Nursery production systems and practices in use prior to emergence of these concerns are being reevaluated, modified or abandoned. There are renewed efforts to reduce input and waste discharge of energy, agricultural chemicals, and water from our nursery production systems. Further relocation and globalization of the nursery industry on new frontiers in response to political, environmental and economic factors is expected. ASHS researchers and educators will develop and disseminate timely information to address these questions in new and appropriate ways.

\section{LITERATURE CITED}

Academy of Natural Sciences, The. 2002. Lewis \& Clark: The importance of plants. http://www.acnatsci.org/museum/lewisclark/l\&c plants.html.

Achten, J. 1999. Kas 2020. IMAG-DLO. http://www.imag.dlo.nl/english/. News, 3 May 1999, press release.

Brownell, A. 1895. Minutes of the sixth semi-annual meeting of the Oregon Association of Nurserymen, Salem, Ore., 2-3 Oct. 1895. Smiley, The Printer, Albany, OR. (OSU Valley Library Vault, SB1,Q7).

Cal Harvest Marketing, Inc.1996. History of California kiwifruit. http: //www.calharvest.com/hock.html.

Campbell, F. 1999. Plants that hog the garden: Invasive plants in the United States. Fine Gardening. http://www.taunton.com/fg/features/plants/invasive/ 1.htm.

Cardwell, J.R. 1909. Early horticultural days in Oregon (address to the State Hor. Soc., Portland, Ore., 7 Dec.). Valley Library, Ore. State Univ., Corvallis. 
Cardwell, J.R. 1913. A brief history of pomology in Oregon. Proc. Amer. Pomol. Soc. Valley Library, Ore. State Univ., Corvallis.

Cochran, K. D. 2000. A history of yews in the United States. Ohio State Univ. Ext. Serv. Ornamental Plants Annu. Rpt. Res. Rev. 2000 Spec. Circ. 177-01. http://ohioline.osu.edu/sc177/sc177_17.html.

Columbian, The. 2003. Clark County History- a look back at Vancouver history. Http://www.columbian.com/reflections/vanc.html.

Davidson, H., R. Mecklenburg, and C. Peterson. 2000. Brief history of the nursery industry, p. 1-20. In: Nursery management, administration and culture. 4th ed. Prentice Hall.

Duruz, W.P. 1910. Notes on the early history of horticulture with special reference to the fruit tree nurseries in Oregon. Proc. Ore. Hort. Soc. 1910.

Duruz, W.P. 1941. History of horticulture in the Pacific Northwest. Agr. Hist. $\mathrm{XV}: 91$.

Ellison, Joseph W. 1937. Beginnings of apple industry in Oregon. Agr. Hist. 11(Oct.):322-342 (Ore. Hist. Soc. Library).

Geneve, Robert. 2001. Plant propagation techniques: A historical perspective. Proc. Intl. Plant Propagators' Soc. 51:370-375.

Govil, S. and S.C. Gupta. 1994. Plant micropropagation industry in India retrospects and prospects. J. Sci. Ind. Res. 53(10):768-777.

Groot, N.S.P. de. 1998. Floriculture worldwide trade and consumption patterns. In: Proceedings of the world conference on horticultural research, Rome, Italy, 17-20 June. Acta Hor. 495:101-121.

Hall, M. 2000. IPlants: Invasive plants and the nursery industry. Undergraduate senior thesis in environmental studies, Spring 2000. Ctr. Environ. Studies, Brown Univ.http://www.brown.edu/Research/EnvStudies_Theses/full9900/ mhall/IPlants/History.html.

Higginbotham, J.S. 1990. Four centuries of planting and progress - A history of the U.S. nursery industry. Amer. Nurseryman 171(12):36-58.

Himes, G.H. 1910. Historical sketch of the Horticultural Society of Oregon. Ore. State Hort. Soc. Proc. 1910, p. 95-96.

Independence Hall Association. 2000. Historic Bartram's Garden. http: //www.ushistory.org/tour/tour_bartram.htm.

Lewelling, S. 1850-1860. Notebooks from the nursery business. On file at the Ore. Hist. Soc..

Loy, W.G. 1976. Atlas of Oregon. Univ. Ore. Books.

Luce, W.A. 1976. Washington. In: W.H. Upshall (ed.). History of fruit growing and handling in United States of America and Canada, 1860-1972. Amer Pomol. Soc.. Regatta City Press LTD, Kelowna, B.C., Canada.

Luelling, J.H. 1952. Bringing the "Traveling Nursery" across the plains in 1847. In: Luelling, Lewelling Llewellyn-Campbell family history and genealogy. Valley Library vault (CS71.L8L8), Ore. State Univ., Corvallis, and Ore. Hist. Soc. Library.

McClintock, T.C. 1967. Henderson Luelling, Seth Lewelling and the birth of the Pacific Coast fruit industry. In: T. Vaughan (ed.). Ore. Hist. Quart., June 1967, LXVIII, No. 2.

McKelvey, B. 1940. The flower city: Center of nurseries and fruit orchards. http://www.history.rochester.edu/flowercity/subdivision.htm. Originally published in The Rochester Hist. Soc. Publ. vol. XVIII (1940):121-169.

Mendelson, K. 2002. Pacific Northwest garden history timeline 1778-1900. http://www.halcyon.com/tmend/timeline.htm.

Minnesota Educational Computing Consortium (MECC). 1996. The history of the Oregon Trail-The historical trail itself. http://www.mecc.com/mecchome/otII.files/otII.history.html.

Oregon Association of Nurserymen. 1997. OAN buyers' guide (http:// www.nurseryguide.com/)
Pacific Monthly. 1902. p. 31-32.

Peterson, T., A. Miller, P. Schnable, R. Shoemaker, J. Wendel, and E. Wurtele. 1997. ISU Plant initiative. Rpt. Comm. Plant Sci.: Directions of plant biology research. http://www.ag.iastate.edu/plantsci/plant.html.

Powers, F.W. 1907. Work of the Pacific Coast Association of Nurserymen. Proc. Pacific Coast Assn. Nurserymen 5th Annu. Mtg. (SB 354.P2, Ore. State Univ. Valley Library).

Reflections - Alook back at Clark County's history. Http://www.columbian.com/ reflections/vanc.html.

Reichard, S. and F. Campbell. 1996. Invited but unwanted. Amer. Nurseryman 184:39-45.

Schulze, R.E. and R.P. Kunz. 1995. Potential shifts in optimum growth areas of selected commercial tree species and subtropical crops in southern Africa due to global warming. Terrestrial ecosystem interactions with global change. 1st GCTE Sci. Conf., Woods Hole, Mass., 23-27 May 1994. J. Biogeogr. 22(4-5):679-688.

Schneider, J. 1990. Retailing renaissance. Amer. Nurseryman 171(12):64-72.

Shugert, R. 1985. Taxus production in the U.S.A. Proc. Intl. Plant Propagators' Soc. 35:149-153.

Smith, S. 1990. Riding the technology express. American Nurseryman 171(12): 168-197.

Thornber, W.S. 1906. Cooperative work of nurseries and experiment stations. Proc. 4th Annu. Mtg. Pacific Coast Assn. Nurserymen (SB354.P2, Ore. State Univ. Valley Library).

Tukey, H.B. 1979. Growth and development of landscape plants: A science comes of age. HortScience 14(3):373-375.

Turning Point Project.1999. Warning bioinvasion, an advertisement. N.Y. Times 20 Sept 1999:A11.

Urbano, C.C. (ed.). 1990. Special issue, Life and times in the industry. Amer. Nurseryman 171(12).

U.S. Department of Agriculture-Current Research Information System. 2002. Current Research Information System (CRIS) web site. 19 Dec. 2002. http: //cris.csrees.usda.gov/

U.S. Department of Agriculture-National Agricultural Statistics Service. 2003. http://www.nass.usda.gov/census/census97/quickfacts/page5.htm, http://www.usda.gov/nass/.

U.S. Department of Agriculture-National Agricultural Statistics Service. 2001. Nursery Crops 2000 Summary. http://usda.mannlib.cornell.edu/reports/nassr/ other/nursery/.

U.S. Department of Agriculture-Economic Reporting Service. 2003. State Fact Sheets. http://www.ers.usda.gov/statefacts/ and Ore. State Fact Sheet. http: //www.ers.usda.gov/statefacts/OR.htm.

White, R.P. 1975 A century of service. A history of the Nursery Associations of the United States. Amer. Assn. Nurserymen, Inc.

Wrenn, S.B. 1939a. Oregon: Early days and ways in and around Milwaukie (interview with Harvey Gordon Starkweather, 4 Jan. 1939). Ore. Folklore Stud.,Amer.Memory - Fed. Writers'Proj., Works Progr.Admin. U.S. Library of Congr. http://lcweb2.loc.gov/wpa/30010924.html.

Wrenn, S.B. 1939b. Oregon: Early horticultural history and lore (interview 30 Jan. 1939 with Mrs. Herman Ledding, Milwaukie, Ore., step-daughter of Seth Lewelling). Ore. Folklore Stud., Amer. Memory-Fed. Writers' Proj., Works Progr. Admin. U.S. Library of Congr. http://lcweb2.loc.gov/ wpa/30010209.html.

Zielinski, Q.B. 1976. Oregon, p. 113-117. In: History of fruit growing and handling in United States of America and Canada, 1860-1972. Amer. Pomol. Soc., Regatta City Press LTD, Canada. 